\title{
Localization of kala-azar in the endemic region of Bihar, India based on land use/land cover assessment at different scales
}

\author{
Gouri S. Bhunia ${ }^{1}$, Shreekant Kesari ${ }^{1}$, Nandini Chatterjee ${ }^{2}$, Vijay Kumar ${ }^{1}$, Pradeep Das ${ }^{1}$ \\ ${ }^{1}$ Department of Vector Biology and Control, Rajendra Memorial Research Institute of Medical Sciences, \\ Agamkuan, Patna - 800 007, Bihar, India; ${ }^{2}$ Department of Geography, Presidency University, Kolkata, \\ WestBengal, India
}

\begin{abstract}
Land cover, a critical variable in the epidemiology of kala-azar, can be remotely characterized by customizing and integrating "state-of-the-art" imagery at different spatial scales from different sensors onboard satellites. A study was conducted at four levels (national, state, district and village) investigating the role of land use/land cover (LULC) for leishmaniasis transmission resulting in a framework highlighting the links between LULC and areas endemic for the disease. Distribution maps were analysed by a probabilistic approach (Bayesian classifier) which produced a set of "suitability estimates" based on the probability of sand fly presence. The development of a sound knowledge of each link in the predicted sequence of satellite views offering an extraordinary opportunity to support the mapping of kala-azar endemicity and stratification of areas suitable for sand fly habitats across the country as well as at the local scale.
\end{abstract}

Keywords: Kala-azar, remote sensing, spatial scale, land use/land cover, India.

\section{Introduction}

Strategies to control and eventually eliminate the problem posed by kala-azar (visceral leishmaniasis) must rely on data expressing transmission based on vector ecology and disease incidence. However, our knowledge of the distribution and abundance of the disease vis-à-vis the presence of Phlebotomus argentipes is still inadequate for the planning of large-scale intervention strategies (Walton et al., 1987; Picado et al., 2010). One way to overcome this dilemma would be to compare the distribution of kala-azar, available from the Ministry of Health and local health offices, with that of potential sand fly habitats derived from land cover datasets which are now readily available in the form of satellite imagery.

Given the ecology of its vectors, leishmaniasis lends itself to spatial analysis. Posteriori risk modelling for kala-azar in Africa and Asia suggests that rainfall, altitude and cultivation patterns can predict the transmission rates (Elnaiem et al., 2003; Sudhakar et al., 2006; Bhunia et al., 2010a). Landscape variables such as land use/land cover (LULC) may be particularly important since they are directly linked to vec-

\footnotetext{
Corresponding author:

Pradeep Das

Department of Vector Biology and Control

Rajendra Memorial Research Institute of Medical Sciences

Agamkuan, Patna 800 007, Bihar, India

Tel. +91 0612 2635570; Fax +9106122364379

E-mail: drpradeep.das@gmail.com
}

tor presence (Feliciangeli et al., 2006). The importance of LULC for sand fly distribution is emphasised by authors using vegetation and other environmental parameters, including meteorological and altitude data, to estimate the geographic limits for various vector species (Sudhakar et al., 2006; Kolaczinski et al., 2008; Bhunia et al., 2010b; Fernández et al., 2010). In this connection, the excellent spatial and spectral resolutions of currently available satellite sensors provide opportunities to explore transmission patterns, distances and environmental factors. Remote sensing and geographical information systems (GIS) are useful for the investigation of both the distribution of the sand fly vector and kala-azar in humans at various scales (Rogers and Williams, 1993; Hay et al., 1996; Sudhakar et al., 2006; Bhunia et al., 2011). There is also a growing literature on the application of satellite imagery for highresolution mapping of sand fly habitats (Wilson, 2002; Claborn, 2008). However, despite the progress made, the accuracy of most sand fly distribution maps is still not detailed enough for planning and implementation of control activities. The effect of LULC is usually considered in this connection, but has not previously been analysed as potential indicator of $P$. argentipes habitats comparing vector suitability vis-à-vis kala-azar incidence. Yet, assessments of suitable climate and vegetation do not only relate to $P$. argentipes ecology but can also indicate availability of definite hosts. However, the environmental features which are particularly important for the 
delineation of the risk for vector exposure cannot be sufficiently well captured by low-resolution data. On the other hand, it has been argued that high-resolution imagery and greater spectral range combined with powerful tools for data management and analysis would enhance the chances of identifying environmental factors and spatio-temporal patterns at the required scale (Wilson, 2002).

The arguments above notwithstanding, low-resolution images are useful for large-scale investigations, e.g. at the national or state levels (Rémi et al., 2007). Mapping at these levels can supply decision-makers with general outlines and provide a comprehensive LULC picture of the endemic regions. The local level, on the other hand, is helpful for quantitative analysis by facilitating applications ranging from land management to ecology models (Kerr and Ostrovsky, 2003; Wulder et al., 2004; Lassau et al., 2005). The specific purpose of this study was to examine the relationship between LULC classes and their suitability for vector habitats in areas endemic for kala-azar at different spatial scales.

Material and methods

\section{Site description}

Two districts endemic for kala-azar in the central part of in the eastern Indian state of Bihar (Fig. 1) were selected for the study: Vaishali $\left(2,036 \mathrm{~km}^{2}\right.$ located between $25^{\circ}$ to $26^{\circ} \mathrm{N}$ latitude and $85^{\circ}$ to $86^{\circ} \mathrm{E}$ longitude) and Muzaffarpur $\left(3,173 \mathrm{~km}^{2}\right.$ located between $26.22^{\circ}$ to $25.55^{\circ} \mathrm{N}$ and $84.53^{\circ}$ to $85.46^{\circ} \mathrm{E}$ ). These districts are located on the floodplains of Ganges and Gandak (a tributary) with the geomorphology typified by perennial and seasonally flowing water courses, both often kept stationary on the plain. The most common soils throughout the region are entisols (which are devoid of clay and organic matter) and inceptisols (recently formed surface soils in unconsolidated parent material). Both districts have a humid tropical climate with average, annual rainfall of 1,200-1,400 $\mathrm{mm}$. On average, the daily, minimum

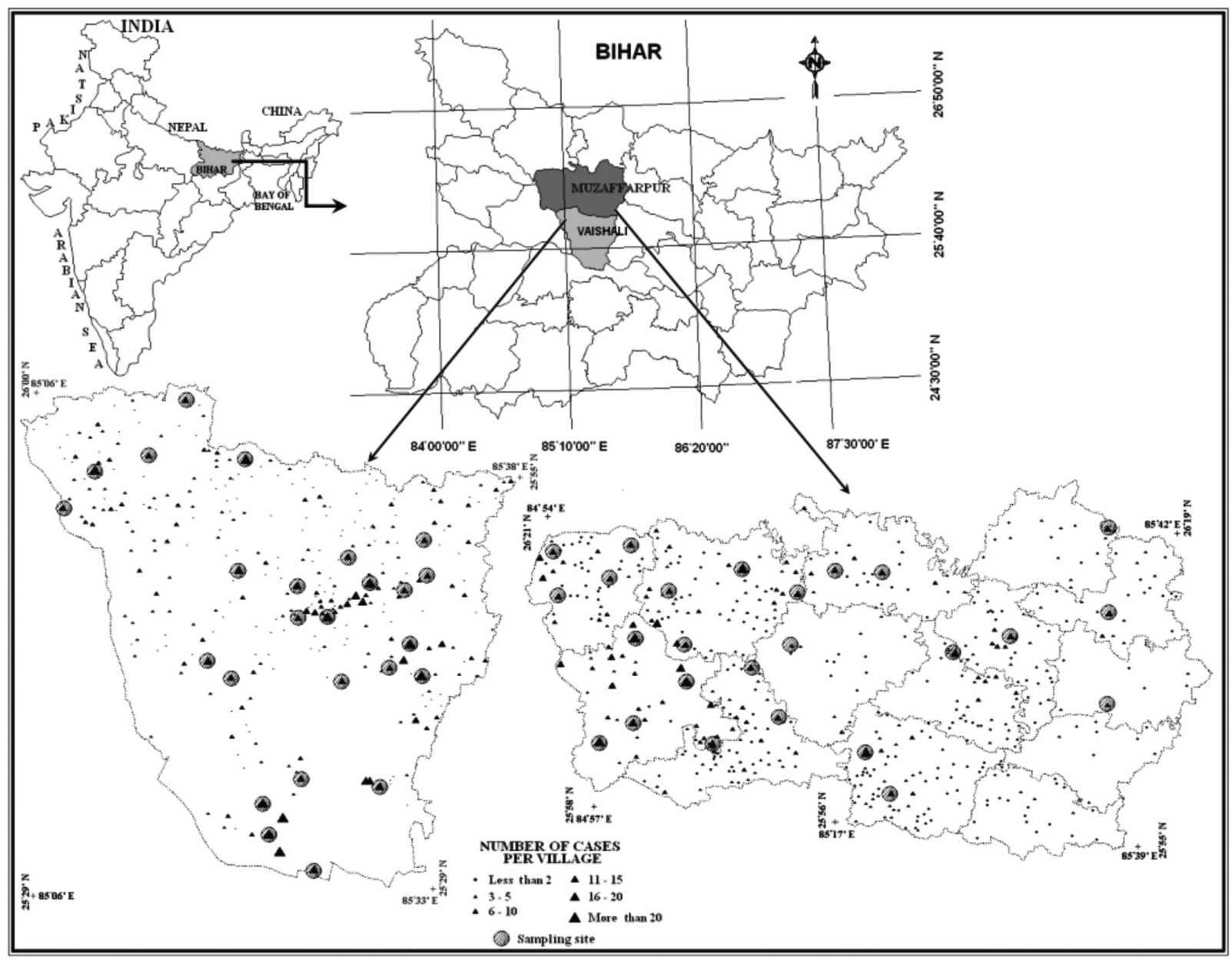

Fig. 1. Map of the study area with insert showing the sampling sites (S1-S50) at the Vaishali and Muzaffarpur districts. 
temperatures are $26.5^{\circ} \mathrm{C}$ in the summer season, $18.7^{\circ} \mathrm{C}$ in the rainy season and $9.4^{\circ} \mathrm{C}$ during the winter season. The corresponding mean maximum temperatures are $36.2{ }^{\circ} \mathrm{C}, 33.5^{\circ} \mathrm{C}$ and $21.7^{\circ} \mathrm{C}$.

\section{Disease incidence}

The kala-azar incidence, based on examination of spleen or bone marrow aspirates employing the rk39 kit (used by the Indian National Vector-Borne Disease Control Programme (NVBDCP), was extracted from records kept by the District Health Offices (DHO) and the Bihar State Health Society (BSHS) for each district for the period of 2007-2009. Data on kala-azar cases at the block level (a district sub-division immediately above the Taluk level, which commonly comprises a few villages and municipalities) for the period 20072009 , were obtained from the local public health centres (PHCs). The village-level incidence was obtained from the PHC and DHO records.

\section{Remote sensing}

The relationship between LULC and vector habitats was analysed at the national, state, district and village levels using various resolutions: very coarse (pixel size $>1,000 \mathrm{~m}$ ), coarse (pixel size $=500 \mathrm{~m}$ ), medium (pixel size $\leq 100 \mathrm{~m}$ ) and high (pixel size $<10 \mathrm{~m}$ ). The measurements were multi-sourced using data from several satellite-based instruments as depicted in Table 1.

The global land cover facility (GLCF, 2000) project provides a harmonised land cover database for the whole globe for the year 2000 (http://www.landcover.org). The spatial resolution is approximately $1,000 \mathrm{~m}$ at the equator and it documents a total of 14 land cover classes. Regional maps of Asia, created as a byproduct under this framework, have more thematic classes than previously published and present the most spatially detailed view published at the continental scale based on data acquired between 1981 and 1994 by the Advanced Very High Resolution Radiometer (AVHRR) sensor (http://earth.esa.int/object/index. cfm?fobjectid=3754). The large-scale data for the study area was obtained from the Global Land Cover by the National Mapping Organization (GLCNMO) (http://www.iscgm.org/browse.html). The spatial resolution used was approximately $500 \mathrm{~km}$ with land cover (and patchy land use) displayed according to 20 classes. In addition, eight periods of the 16-day composite 7-band Moderate Resolution Imaging Spectroradiometer (MODIS) data (http://modis.gsfc. nasa.gov/data/) from 2003 were downloaded from the Global Mapping Project website (http://www.iscgm .org/). For the analytic work, areas with recorded kala-azar incidence rates for each village (using $1,000 \mathrm{~m}$ diameter buffer zones) were overlaid on LULC maps produced by AVHRR and GLCNMO.

The analyses at the district level were based on Landsat satellite imagery, acquired on November 7, 2009 by the Thematic Mapper (TM) sensor (http://earth.esa.int/object/index.cfm?fobjectid=1496) (Path/Row-141/42) (http://edcsns17.cr.usgs.gov/New EarthExplorer/). The map is in raster format at the 1:50,000 scale. The LULC classes were selected on the basis of likely biological significance for kala-azar vector habitats. At the village level, the identification of the risk factor was based on the Indian Remote Sensing Satellite P6 (IRS-P6) equipped with the Linear Imaging Self Scanning IV sensor (LISS IV) (http://www. euromap.de/docs/doc_005.html). LISS IV scenes with

Table 1. Origin of the data used in the study.

\begin{tabular}{|c|c|c|c|c|}
\hline \multirow{2}{*}{ Feature } & \multicolumn{4}{|c|}{ Satellite sensor } \\
\hline & AVHRR & MODIS & Landsat TM & LISS IV* \\
\hline Average altitude & 833 km & $705 \mathrm{~km}$ & $705 \mathrm{~km}$ & 817 km \\
\hline \multirow{2}{*}{ Swath width } & \multirow{2}{*}{$2,253 \mathrm{~km}$} & Cross track $=2,330 \mathrm{~km}$ & \multirow{2}{*}{$185 \mathrm{~km}$} & Multispectral $=23.9 \mathrm{~km}$ \\
\hline & & & & \\
\hline & & & & \\
\hline Temporal resolution & Daily & Daily & 16 days & 5 days \\
\hline Spatial resolution & $1,100 \mathrm{~m}$ & $\begin{array}{l}\text { Bands } 1-2=250 \mathrm{~m} \\
\text { Bands } 3-7=500 \mathrm{~m} \\
\text { Bands } 8-36=1,000 \mathrm{~m}\end{array}$ & $\begin{array}{l}\text { Bands } 1-5=30 \mathrm{~m} \\
\text { Band } 6=120 \mathrm{~m} \\
\text { Band } 7=30 \mathrm{~m}\end{array}$ & $5.8 \mathrm{~m}$ \\
\hline Spectral range & $0.58-12.5 \mu \mathrm{m}$ & $0.62-2.155 \mu \mathrm{m}$ & $0.45-12.4 \mu \mathrm{m}$ & $0.52-0.86 \mu \mathrm{m}$ \\
\hline Radiometric resolution & 10 bits & 12 bits & 8 bits & 7 bits \\
\hline
\end{tabular}

*See LISS IV-IRS-P6 Data Users manual (http://en.wikipedia.org/wiki/Moderate-Resolution_Imaging_Spectroradiometer) 
Date of Pass (DOP) for the study were collected on February 12, 2009, May 19, 2009 and June 12, 2009 with the following paths/rows 102/4, 102/5, 102/6, $102 / 15,102 / 16,102 / 17,102 / 53$ and 102/54. At the district and village levels, the buffer zones used for the analysis consisted of areas covered by circles with a diameter of $500 \mathrm{~m}$ diameter.

The thresholds for the definition of the suitability category are displayed in Table 2 . This approach for delineation of this disease, defined as inductive by Corsi et al. (2000), was used for sourcing the distribution of the environmental requirements of the sand fly vector, in this case using information implicit in the habitat maps.

\section{Image registration and classification}

The imagery was registered at the Universal Transverse Mercator (UTM) projection (Zone $45 \mathrm{~N}$ and Datum - World Geodetic Systems (WGS) -84) (Gonçalves and Morgado, 2008; Schetselaar et al., 2008) and based on the second-order polynomial algorithm and the nearest neighbour resampling method (Turner and Congalton, 1998; ELtohamy and Hamza, 2009). Mosaics were created from all satellite scenes covering the study area with the sample sites cropped based on the buffer zone chosen. At the national and state levels, the buffer zones consisted of areas covered by circles with a diameter of $1,000 \mathrm{~m}$, whereas the $500 \mathrm{~m}$ diameter was chosen for the district and village levels. These buffer zones were centred at each highly affected village ( $>10$ cases of kalaazar) to estimate the land cover classes suitable for vector habitats within the region. The LULC map was generated using a supervised classification approach based on the Gaussian maximum likelihood classifier (Jung and Swain, 1993; Miao et al., 2007). Relevant LULC classes suitable for kala-azar transmission were identified through literature survey and information collected during field visits to the affected region.

\section{Comparison between the four approaches}

The results of the analysis at the national, state, district and village levels were matched to determine how closely the results of the various approaches corresponded. To better determine the critical environmental features searched in the two districts, different land cover resolutions were used for the various levels investigated, i.e. $1,000 \mathrm{~m}$ pixel size (very coarse resolution) at the national level, 250 to $500 \mathrm{~m}$ pixel size at the state level, $30 \mathrm{~m}$ pixel size (medium resolution) at the district level, and $5.8 \mathrm{~m}$ pixel size (high-resolution)
Table 2. Category classes of LULC suitability with respect to sand fly habitats.

\begin{tabular}{ccc}
\hline Information value $\left(I_{j}\right)$ & Sand fly suitability & Suitability index \\
\hline$>1.50$ & Very high & 4 \\
$1.00-1.50$ & High & 3 \\
$0.50-1.00$ & Moderate & 2 \\
$0-0.50$ & Low & 1 \\
$<0.00$ & Negligible & 0 \\
\hline
\end{tabular}

at the village level. Although it is not possible to directly link land cover classes with vector abundance and kala-azar incidence, the relationships among the classifications can still be defined statistically across the affected villages by inclusion of all four levels in the analysis. The LULC classes describes land cover according to a hierarchical series of classifiers and attributes and separates surfaces with vegetation from barren ones, terrestrial areas from water-bodies, cultivated, managed land from natural and semi-natural areas, etc. This allows area-weighted average estimates for sand fly habitat suitability, a precision-enhancing parameter that was used here to improve the chance of detecting areas at risk for kala-azar.

The potential of these newly generated maps to describe and depict kala-azar vector habitats was evaluated using a simplified approach, based on thematic aggregation classes. Our purpose was to arrive at a defined, customised LULC indicator for P. argentipes presence. A variable indicator based on aggregates from ten (TM) and 12 (LISS IV) units was derived to represent the land covers relevant for sand fly ecology. The LULC classes were ranked according to their sand fly habitat suitability, i.e. indicating their potential risk for kala-azar transmission. The scores were derived from the literature, expert opinion and the information value $\left(I_{j}\right)$, the latter calculated by the equation:

$$
I_{j}=\log _{10}(\text { class density/map density) }
$$

where the class density is the number of LULC classes within a buffer zone divided by the number of such classes within the study area, and map density the proportion of the entire LULC map covered by endemic kala-azar. The suitability of a land cover class as a predictor of sand fly habitat is therefore based on the intrinsic features with no a priori assumption on how land cover classes shape a landscape's overall pattern.

\section{Analysis of the suitability index}

For this study, 50 villages (25 from each district) were selected randomly but excluding villages free 
from kala-azar. Two sizes of buffer zones were tested since the active flight range of the sand fly is not precisely known. Conditional analysis, which attempts to assess the probabilistic relationship between factors affecting kala-azar epidemics and LULC characteristics, was applied (Prakash, 1998; Suresh, 1999). The technique is based on Bayes' theorem (Bayesian classifier) (http://www.isle.org/ langley/bayes.html), according to which frequency data can be used to calculate the probability that depends on knowledge of previous events, in this case kala-azar outbreaks. In this analysis, the $I_{j}$ values were ranked with an index ranging from 4 to 0 , corresponding to five broad categories of suitability, i.e. very high, high, moderate, low and very low or negligible (Table 2).

\section{Results}

\section{National level}

The AVHRR data indicates that $62 \%$ of the area investigated, i.e. the total expanse of the Vaishali and Muzaffarpur districts $\left(>5,000 \mathrm{~km}^{2}\right)$, is covered by agricultural land and water-bodies (Table 3). Areas associated with water-bodies, closed shrub land, and settled areas are the main places where kala-azar can be expected $(38 \%)$. The fact that the highest information values were attained from areas associated with water bodies, closed shrub land and urban areas indicates that these features are likely to contain vector habitats and, in consequence, contribute to increased incidence of kala-azar (Table 7). Agricultural land and grassland, on the other hand, represented low information values and are consequently less suitable for the vector.

\section{State level}

The higher spatial resolution of the MODIS data reinforces the LULC classification based on AVHRR and provides also a more detailed picture of the landscape. Three quarters of the study area is shown to be covered by agricultural land and paddy fields with rest comprising mainly open land with sparse vegetation (Table 4). At this level, only a minor part of the total area seemed suitable for vector habitats. The highest information values were attained from bare areas or places with sparse or herbaceous vegetation, which indicates that these features support the presence of vectors and, accordingly, contribute to the risk for kala-azar (Table 8). The analysis also shows that agricultural land, paddy fields, forests and urban areas are less suitable for the vector.

\section{District level}

Critical factors in sand fly ecology and habitat demarcation appeared at this level, which is based on the Landsat TM imagery. Ten LULC classes, with special emphasis on crops, vegetation and fallows, were investigated for suitability with respect to kalaazar with the overall aim to score them for endemic risk. Defined by the supervised classification method, $85 \%$ of the total area comprised agricultural fallow fields, paddy fields and mixed vegetation, with the remaining $15 \%$ consisting of land associated with water-bodies, marshy land, moist and dry fallow, sandy areas, plantations and settlements (Table 5).

High suitability for sand fly habitats was attributed to marshy land, dry or moist fallow and settlements, but areas associated with water-bodies, sandy areas and plantations also indicated relatively high suitability (Table 9). With reference to the estimates presented in Table 9, it should be noted that some classes (e.g. agricultural land, used or laying fallow) had less influence with regard to habitat suitability, representing the same LULC classes as those at the national and state

Table 3. LULC classes at the national level (derived from AVHRR).

\begin{tabular}{|c|c|c|c|}
\hline Sample site & Characteristics & Area covered & Suitability \\
\hline Area near water-bodies & $\begin{array}{l}\text { Areas associated with lakes, permanent and seasonal flowing water courses, } \\
\text { channels and ponds }\end{array}$ & $21 \%$ & 2 \\
\hline Closed shrub land & Shrubs (1-2 $\mathrm{m}$ in height) covering $70 \%$ of the area investigated & $5 \%$ & 2 \\
\hline Open shrub land & Shrubs (1-2 $\mathrm{m}$ in height) covering $10-30 \%$ of the area investigated & $9 \%$ & 1 \\
\hline Open grassland & Grass plains with herbaceous plants & $12 \%$ & 0 \\
\hline Agricultural land & Land primarily used for the production of cereals based on seasonal crops & $41 \%$ & 0 \\
\hline Urban areas/settlement & $\begin{array}{l}\text { Residential areas of various density, including land used for mining and } \\
\text { transportation }\end{array}$ & $12 \%$ & 2 \\
\hline
\end{tabular}


Table 4. LULC categories at the state level (derived from MODIS).

\begin{tabular}{|c|c|c|c|}
\hline Sample site & Characteristics & Area covered & Suitability \\
\hline Areas near water-bodies & $\begin{array}{l}\text { Areas associated with lakes, permanent and seasonal flowing water courses, } \\
\text { channels and ponds }\end{array}$ & $2 \%$ & 1 \\
\hline $\begin{array}{l}\text { Sparse vegetation, trees } \\
\text { and open land }\end{array}$ & Areas dominated by trees but with $\geq 75 \%$ of open land & $9 \%$ & 3 \\
\hline Shrubs & $\begin{array}{l}\text { Sparse vegetation with early secondary growth of perennial plants and fruit } \\
\text { (banana, mango, lychee) }\end{array}$ & $5 \%$ & 1 \\
\hline Herbaceous vegetation & $\begin{array}{l}\text { Areas dominated by grass plains and non-graminoid plants such as forbs, } \\
\text { commonly utilized for grazing }\end{array}$ & $<2 \%$ & 2 \\
\hline Agricultural land & Land primarily used for the production of cereals based on seasonal crops & $37 \%$ & 0 \\
\hline Paddy fields & Fields exclusively used for the cultivation of rice and other semi-aquatic crops & $38 \%$ & 0 \\
\hline Bare areas (consolidated) & Areas of degraded soil with almost no vegetation & $<1 \%$ & 3 \\
\hline $\begin{array}{l}\text { Mixed broad-leaf/ } \\
\text { evergreen forest }\end{array}$ & Stratified old secondary vegetation and mature planted trees & $5 \%$ & 0 \\
\hline Settled areas & Human settlements or various residential developments in urban or rural areas & $<2 \%$ & 0 \\
\hline
\end{tabular}

levels.

Village level

The LULC classes at this level were derived from LISS IV and have the highest resolution. To recognise the suitable habitat areas, the LULC categories were categorised into 12 types as can be seen in Table 6 . Indeed, close to $58 \%$ of the area within the region is dominated by agricultural land including paddy fields, while $28 \%$ is covered by plantations, areas associated with water-bodies and moist fallow and $14 \%$ by weeds, grasses, sparse vegetation, river/canal, sand/marshy land, dry fallow and settlements.

The results for the sand fly habitat analysis show the kala-azar affected areas as highly influenced by moist fallow, river/canal and sandy areas of (Table 10).
Interestingly, the analysis highlights the high suitability of some LULC types occupying grass/weeds covers land, marshy land, dry fallow, areas associated with water-bodies and settlements. The plantation class assigned as medium potential for the sand fly habitat, whereas agricultural land, used or laying fallow, and sparse vegetation had less potential for sand fly habitats and thus also for kala-azar (Table 10).

\section{Discussion}

Environmental factors that directly influence vector density have previously been shown to be associated with risk for kala-azar (Elnaiem et al., 2003; Sudhakar et al., 2006; Bhunia et al., 2010a,b, 2011). The spatial resolution can vary from less than $10 \mathrm{~m}$, for example

Table 5. LULC classes at the district level (derived from Landsat TM).

\begin{tabular}{|c|c|c|c|}
\hline Sample site & Characteristics & Area covered & Suitability \\
\hline Agricultural fallow & Tilled but not planted areas which do not exhibit any visible vegetation & $40 \%$ & 0 \\
\hline Paddy fields & Fields exclusively used for the cultivation of rice and other semi-aquatic crops & $20 \%$ & 1 \\
\hline Mixed, sparse vegetation & Perennial plants and fruit cultivation but otherwise only sparse vegetation & $25 \%$ & 2 \\
\hline Areas near water-bodies & $\begin{array}{l}\text { Areas associated with lakes, permanent and seasonal flowing water courses, } \\
\text { channels and ponds }\end{array}$ & $4 \%$ & 3 \\
\hline Marshy land & Areas of water bodies covered with succulent weeds and grass & $>1 \%$ & 4 \\
\hline Moist fallow & Areas where the soil and sub-soil is periodically saturated by water & $>1 \%$ & 4 \\
\hline Dry fallow & Area characterized without vegetation consisting of unusable/unsaturated land & $<1 \%$ & 4 \\
\hline Sandy areas & Naturally occurring granular material in the river basins & $<1 \%$ & 3 \\
\hline $\begin{array}{l}\text { Settlements with } \\
\text { plantation }\end{array}$ & Areas dominated by non-natural wood vegetation associated with settlements & $7 \%$ & 3 \\
\hline Other settlements & Dense residential areas & $>1 \%$ & 4 \\
\hline
\end{tabular}


Table 6. LULC classes at the village level (derived from LISS IV).

\begin{tabular}{llcc}
\hline Sample site & \multicolumn{1}{c}{ Characteristics } & Area covered & Suitability \\
\hline Agricultural fallow & Tilled but not planted areas which do not exhibit any visible vegetation & $32 \%$ & 1 \\
Paddy field & Fields exclusively used for the cultivation of rice and other semi-aquatic crops & $26 \%$ & 1 \\
Weeds/grass land & Seasonal grasses, commonly grazed by cattle including elephant grass, azolla, etc. & $5 \%$ & 3 \\
Plantation & Areas dominated by non-natural woody vegetation & $9 \%$ & 2 \\
Sparse vegetation & Areas dominated by peri-domestic vegetation and covered with $10-20 \%$ & $<1 \%$ & 1 \\
River/canal & woody trees & $>1 \%$ & 4 \\
Sandy areas & Natural, permanent and seasonally flowing water course & $2 \%$ & 4 \\
Area near water-body & Naturally occurring granular material in the river basin & $7 \%$ & 3 \\
Marshy land & Areas associated with lakes, permanent and seasonal flowing water courses, & $>2 \%$ & 3 \\
Moist fallow & Areas of water bodies covered with succulent weeds and grass & $12 \%$ & 4 \\
Dry fallow & Areas where the soil and sub-soil is periodically saturated by water & $>2 \%$ & 3 \\
Settlement & Areas characterised without vegetation consisting of unusable/unsaturated land & $>2 \%$ & 3 \\
\hline
\end{tabular}

when the study site is limited to a village (Feliciangeli et al., 2006), to hundreds of kilometers when entire countries are taken into account (Chaves and Pascual, 2006). However, it remains unclear what degree of resolution is required for useful prediction. Our study benefitted by access to the most recent, freely available datasets of land cover based on high-resolution satellite imagery. Combined with epidemiological data on disease incidence and habitat preference of the sand fly vector, high-resolution spatial data facilitates the study of the interplay between vector-borne diseases and their environment. However, from the perspective of the present study, which is focused on delineating the land cover preferences of the sand fly, the main limitation remains the resolution and accuracy of the kalaazar habitat maps available. These maps have not undergone extensive field validation as updating and upgrading at the national level would require longterm studies. The significance of our approach lays in its success in predicting the overall distribution of areas suitable for the vectors, which is due to the different sensor resolutions (four in this case) and the fact that a thorough LULC analysis can predict the probability for disease transmission. The fact that the highest information value was attained from areas near water bodies, closed and open shrub land and urban areas indicates that these features positively influence the likelihood of vector habitats.

Spatial resolution can be expressed as the terrestrial expanse covered by one pixel, while the scale describes the level at which something, in this case a geographical unit, can be abstracted and represented. Coarse spatial resolution datasets such as those derived from the AVHRR (1.1 km spatial resolution), the foundation of many large area mapping investigations, are often dominated by mixed pixels (Belward et al., 1999; Cihlar, 2000). However, the processes of landscape characteristics identification, and more broadly host vector contact, operate on a very fine spatial scale. The analysis of these relationships at coarser scales (e.g. at the country or regional level) could therefore easily obscure important local patterns that affect transmission of pathogens directly. Thus, the study of an image at different scales is easier to analyse than one presented at different resolutions. However, dependencies cannot be analysed by just changing the resolution of the imagery as this would lead to the loss of variable amounts of useful information as discussed in the eCognition 4.0 users guide of 2004 (http://www.gis. unbc.ca/help/software/ecognition4/ELuserguide.pdf provided by the Definiens $\mathrm{GmbH}$ company (http://www.definiens.com/). In order to analyse an image successfully it is necessary to represent its content at several scales simultaneously and to explore hierarchical scale dependencies. Thus, the choice of an appropriate scale for a particular application depends on several factors, including the information desired about the ground scene, the analysis methods to be used to extract this information and the spatial structure of the scene itself.

Previous studies have shown that kala-azar is highly 


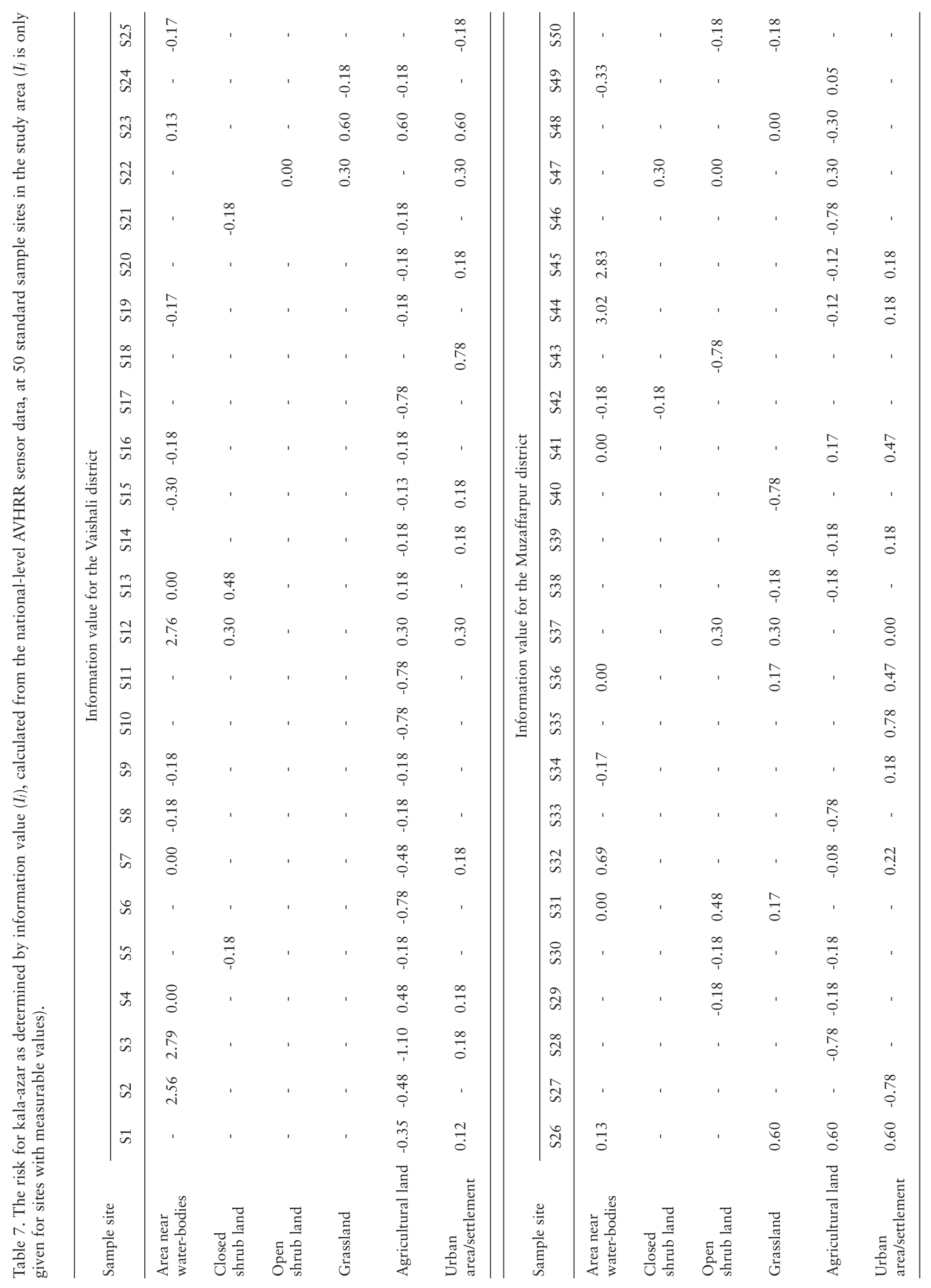


G.S. Bhunia et al. - Geospatial Health 6(2), 2012, pp. 177-193

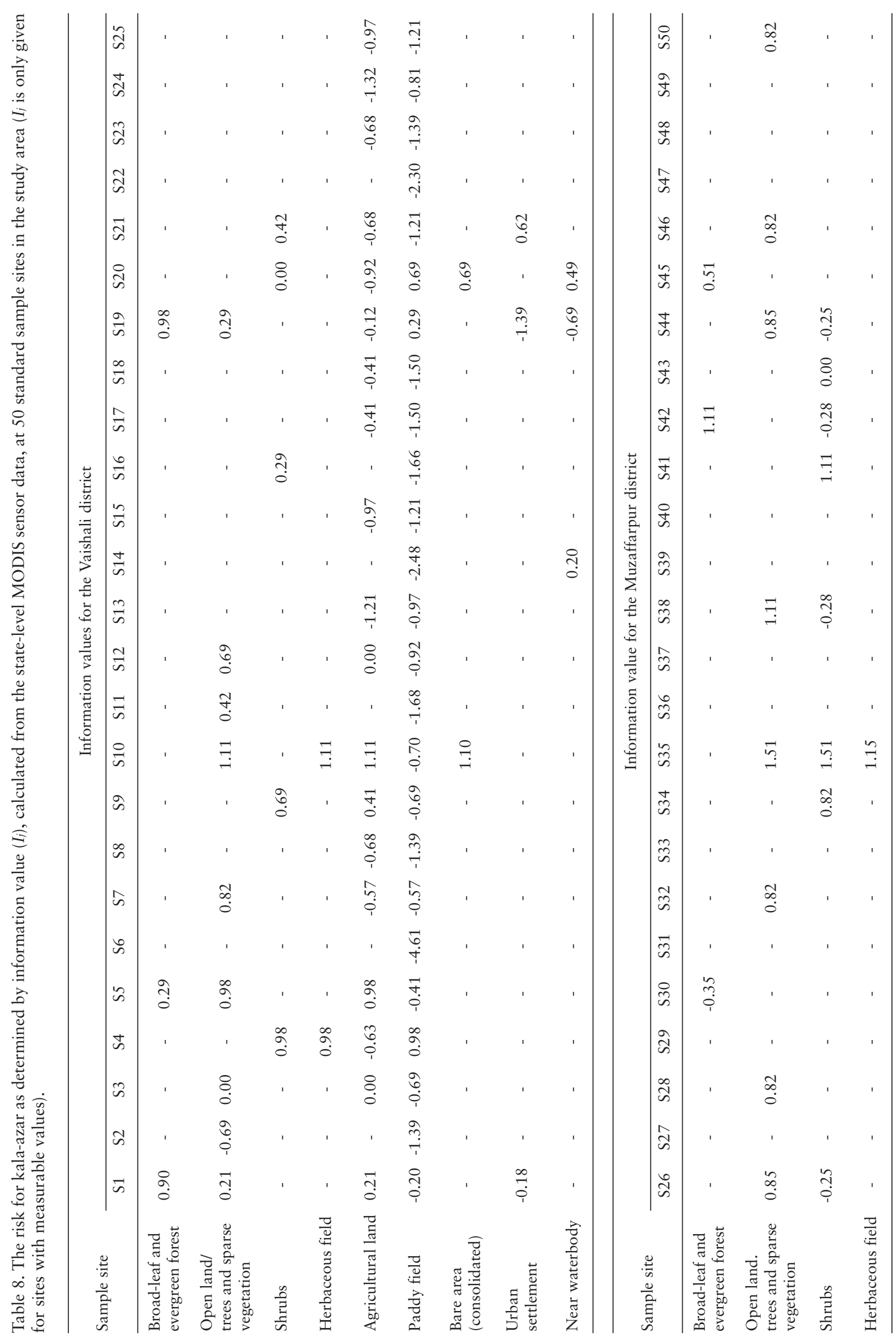




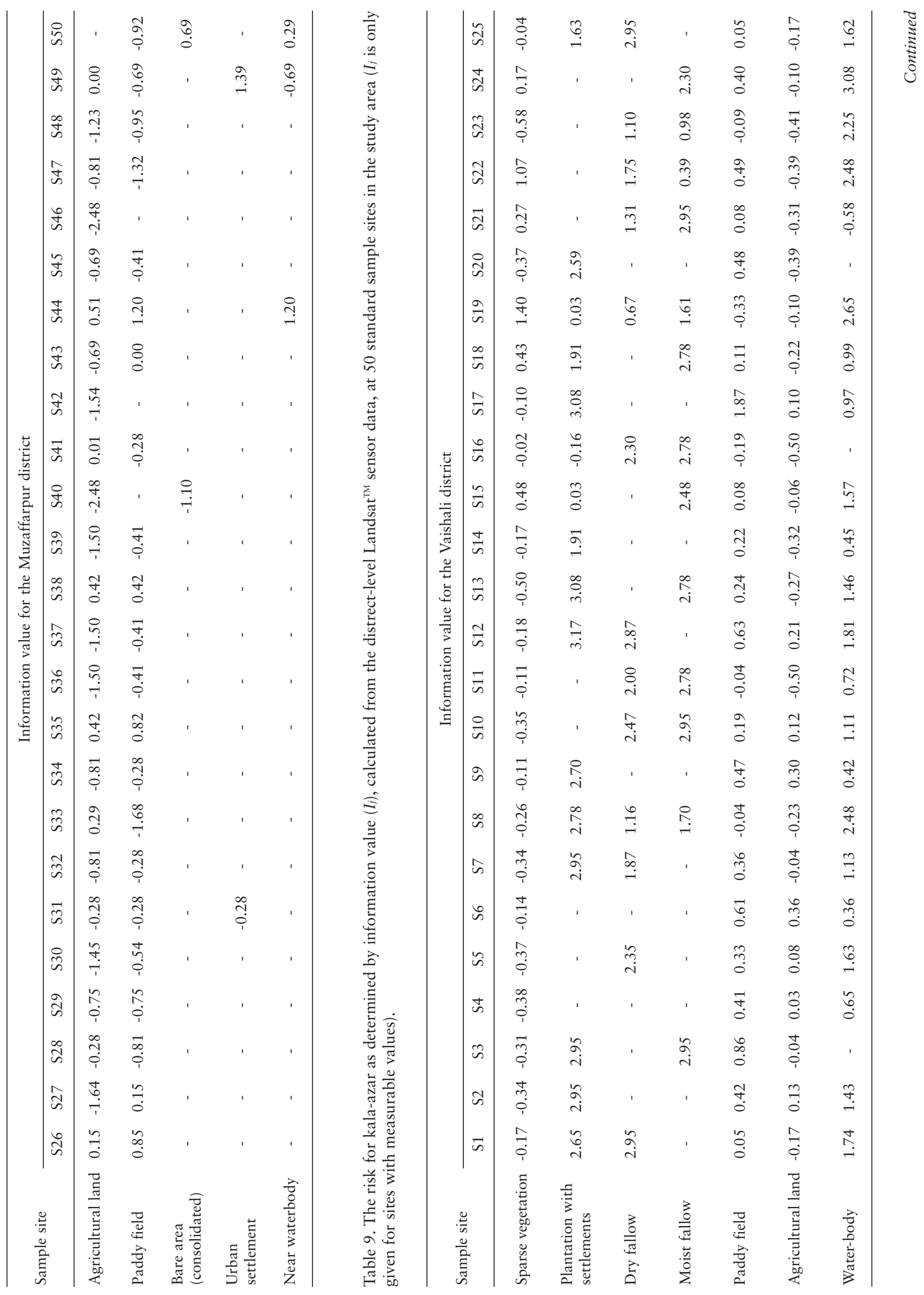




\begin{tabular}{|c|c|c|c|c|c|c|c|c|c|c|c|c|c|c|c|c|}
\hline & జ) & $\stackrel{n}{n}$ & ' & $\begin{array}{l}\infty \\
\infty \\
0 \\
0\end{array}$ & & 号 & 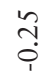 & $\begin{array}{l}\infty \\
0 \\
0 \\
1\end{array}$ & ' & . & $\stackrel{?}{\circ}$ & $\tilde{\pi}$ & 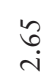 & $\widehat{\widehat{G}}$ & ' & $\stackrel{\text { }}{\rightarrow}$ \\
\hline & ત્ర & $\tilde{\sigma}$ & ' & $\hat{n}$ & & fे & $\begin{array}{l}\text { ò. } \\
\text { in }\end{array}$ & $\begin{array}{l}0 \\
\stackrel{0}{0}\end{array}$ & 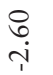 & ' & $\begin{array}{l}\text { ț } \\
\stackrel{0}{1}\end{array}$ & $\begin{array}{l}\infty \\
\stackrel{0}{0} \\
\stackrel{1}{1}\end{array}$ & ñ & 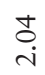 & ' & $\stackrel{+}{\stackrel{+}{\sim}}$ \\
\hline & స్రి & $\stackrel{\bullet}{\stackrel{\leftrightarrow}{-}}$ & $\stackrel{?}{0}$ & 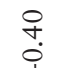 & & 文 & तె & $\stackrel{2}{\circ}$ & , & $\stackrel{\infty}{\rightarrow}$ & $\stackrel{n}{o}$ & ?a & के & $\stackrel{R}{r}$ & ' & $\begin{array}{l}m \\
0 \\
0\end{array}$ \\
\hline & స్ర & $\stackrel{n}{\grave{j}}$ & ' & సై & & 先 & $\stackrel{\partial}{\circ}$ & $\stackrel{n}{\mathrm{j}}$ & ' & $\overrightarrow{\vec{i}}$ & $\begin{array}{l}\stackrel{0}{0} \\
\vdots\end{array}$ & $\begin{array}{l}0 \\
\dddot{1} \\
\stackrel{1}{0}\end{array}$ & $\stackrel{\Re}{0}$ & $\begin{array}{l}+ \\
\text { t. } \\
0\end{array}$ & ' & $\stackrel{n}{n}$ \\
\hline & $\vec{\sigma}$ & $\underset{\mathrm{i}}{\vec{i}}$ & ' & 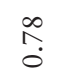 & & 卢 & 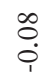 & $\stackrel{n}{\hat{i}}$ & , & $\stackrel{\infty}{\vec{i}}$ & $\begin{array}{l}\text { गे } \\
\text { i. }\end{array}$ & $\begin{array}{l}\text { ¿ } \\
\stackrel{1}{1}\end{array}$ & $\stackrel{\text { ô }}{i}$ & $\stackrel{n}{0}$ & $\stackrel{n}{n}$ & శై \\
\hline & స్ & $\begin{array}{l}0 \\
3 \\
0\end{array}$ & ' & 苛 & & 号 & $\begin{array}{l}\vec{b} \\
\stackrel{0}{0}\end{array}$ & $\stackrel{\infty}{\vec{j}}$ & $\underset{\sim}{\stackrel{\sim}{\leftrightarrow}}$ & ?ִ & 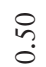 & 角 & 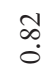 & $\stackrel{\infty}{\stackrel{\infty}{\infty}}$ & , & $\begin{array}{l}\stackrel{0}{0} \\
\stackrel{0}{0}\end{array}$ \\
\hline & $\vec{\omega}$ & & $\stackrel{\text { ș }}{\rightarrow}$ & $\begin{array}{l}n \\
\infty \\
0 \\
0\end{array}$ & & 意 & ?ִ & ' & 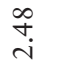 & $\begin{array}{l}n \\
\tilde{i}\end{array}$ & $\vec{f}$ & $\stackrel{\tilde{o}}{0}$ & $\begin{array}{l}\infty \\
\vdots \\
0\end{array}$ & în & , & ऊे \\
\hline & $\stackrel{\infty}{\varpi}$ & $\stackrel{\infty}{\stackrel{\infty}{i}}$ & ' & $\stackrel{\hat{\imath}}{\hat{0}}$ & & f & $\begin{array}{l}\stackrel{a}{0} \\
\dot{0}\end{array}$ & ' & f. & $\stackrel{\text { fे }}{\circ}$ & $\stackrel{a}{\circ}$ & $\begin{array}{l}n \\
0 \\
0\end{array}$ & 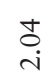 & $\underset{\mathrm{i}}{\mathrm{i}}$ & ' & 尺̂. \\
\hline & $\vec{n}$ & 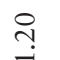 & ' & $\stackrel{+}{\stackrel{N}{*}}$ & & y & $\stackrel{\leftrightarrow}{\leftrightarrow}$ & , & $\bar{\sigma}$ & $\hat{\alpha}$ & $\stackrel{+}{m}$ & $\stackrel{7}{?}$ & 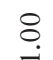 & $\stackrel{\circ}{+}$ & , & $\tilde{2}$ \\
\hline t & $\begin{array}{l}\overrightarrow{0} \\
\ddot{\sim}\end{array}$ & $\stackrel{\vec{j}}{\vec{j}}$ & ' & ت্ర0 & $\stackrel{\breve{\breve{E}}}{E}$ & 离 & $\stackrel{n}{0}$ & , & 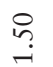 & $\stackrel{N}{\stackrel{N}{r}}$ & $\stackrel{\circ}{\circ}$ & $\stackrel{\infty}{\circ}$ & 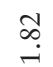 & $\stackrel{?}{\rightarrow}$ & . & $\hat{n}$ \\
\hline 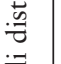 & $\stackrel{n}{\infty}$ & $\begin{array}{l}\hat{\infty} \\
\text { co }\end{array}$ & , & $\stackrel{?}{\rightarrow}$ & $\bar{z}$ & 움 & in & , & $\stackrel{\kappa}{\alpha}$ & $\overrightarrow{7}$ & $\vec{\infty}$ & $\stackrel{m}{\text { fo }}$ & , & in & . & $\vec{m}$ \\
\hline 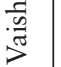 & $\vec{\Delta}$ & $\stackrel{?}{?}$ & ' & $\vec{\jmath}$ & 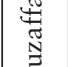 & $\hat{\tilde{n}}$ & กิ & , & , & $\stackrel{n}{\Omega}$ & $\bar{\infty}_{0}$ & తి? & $\hat{\jmath}$ & $\stackrel{\mathcal{F}}{\sim}$ & . & $\vec{m}$ \\
\hline $\begin{array}{l}5 \\
5 \\
5\end{array}$ & $\cong$ & $\stackrel{\infty}{\Re}$ & , & $\bar{\sigma}$ & $\begin{array}{l}\text { gn } \\
\end{array}$ & $\infty$ & q. & m. & . & $\stackrel{\infty}{n}$ & $\bar{n}$ & กุ & $\stackrel{\infty}{\curvearrowright}$ & f & , & $\stackrel{n}{r}$ \\
\hline$\frac{\frac{\partial}{\sigma}}{\sigma}$ & N & $\circ$ & & $n$ & $\stackrel{8}{2}$ & $\widehat{N}$ & $\vec{d}$ & & 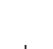 & & $\infty$ & 잉 & & $n$ & & 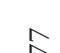 \\
\hline$\vec{z}$ & & $\vec{i}$ & & $\rightarrow$ & $\frac{\vec{J}}{5}$ & $n$ & $\dot{0}$ & & & ' & i & $\dot{0}$ & ' & - & ' & $\because$ \\
\hline 芯 & $\bar{n}$ & 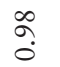 & ' & $\stackrel{N}{\hat{O}}$ & 节 & চ & $\stackrel{\sigma}{\circ}$ & , & , & $\stackrel{\leftrightarrow}{\sigma}$ & $\stackrel{\infty}{\rightarrow}$ & $\begin{array}{l}\vec{f} \\
\vdots\end{array}$ & 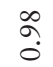 & 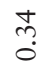 & , & $\begin{array}{l}\infty \\
\infty \\
0\end{array}$ \\
\hline & $\stackrel{\circ}{\infty}$ & $\underset{-}{\sigma}$ & . & $\stackrel{\infty}{\stackrel{\infty}{0}}$ & $\underset{\stackrel{D}{0}}{\stackrel{D}{!}}$ & $\begin{array}{l}n \\
\tilde{n}\end{array}$ & ริ. & 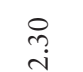 & , & $\begin{array}{l}\stackrel{\tilde{n}}{i} \\
\vec{i}\end{array}$ & $\begin{array}{l}\text { bे } \\
0\end{array}$ & $\begin{array}{l}\stackrel{0}{?} \\
\stackrel{1}{1}\end{array}$ & $\begin{array}{l}\text { b } \\
\text { in }\end{array}$ & $\begin{array}{l}+ \\
\vdots \\
0\end{array}$ & $\begin{array}{l}n \\
\dot{i}\end{array}$ & $\begin{array}{c}\vec{\infty} \\
0 \\
0\end{array}$ \\
\hline & के & $\stackrel{n}{\hat{0}}$ & , & $\stackrel{\infty}{\stackrel{\infty}{r}}$ & & 芯 & $\begin{array}{c}m \\
\substack{i \\
i}\end{array}$ & ' & $\stackrel{\infty}{\circ} \stackrel{0}{\circ}$ & $\stackrel{\substack{+i}}{ }$ & ڤे & \begin{tabular}{l}
$\tilde{n}$ \\
\multirow{1}{*}{}
\end{tabular} & $\stackrel{R}{i}$ & $\begin{array}{l}\stackrel{0}{0} \\
\stackrel{0}{\circ}\end{array}$ & $\begin{array}{l}\stackrel{\infty}{\hat{i}} \\
\text { ind }\end{array}$ & $\tilde{n}$ \\
\hline & $\infty$ & $\underset{\text { i }}{8}$ & . & $\hat{o}$ & & $\ddot{n}$ & $\stackrel{\infty}{\circ}$ & , & , & $\stackrel{8}{0}$ & $\stackrel{\infty}{+}$ & $\bar{m}$ & के & نٌٍْْ & , & $\stackrel{\infty}{\sigma}$ \\
\hline & $\hat{\omega}$ & $\stackrel{N}{N}$ & . & ț & & $\approx$ & $\stackrel{\overbrace{}}{\stackrel{m}{2}}$ & , & $\stackrel{\infty}{\stackrel{\infty}{.} .}$ & , & 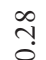 & $\stackrel{0}{\because}$ & กิ & in & , & 6 \\
\hline & ڤ̊ & $\stackrel{q}{q}$ & , & $\tilde{3}$ & & $\vec{\infty}$ & యे. & $\stackrel{\infty}{\stackrel{\infty}{d}}$ & , & : & F & 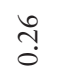 & $\stackrel{\text { f }}{\mathrm{d}}$ & $\underset{0}{ \pm}$ & , & $\stackrel{0}{\stackrel{0}{0}}$ \\
\hline & $n$ & $\stackrel{\circ}{\circ}$ & , & ț & & $\infty$ & 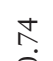 & , & in & สุ & $\ddot{0}$ & $n$ & 8 & $\stackrel{\sim}{\infty}$ & . & $\stackrel{+}{m}$ \\
\hline & 吕 & 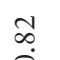 & , & $\stackrel{+}{\infty}$ & & के & 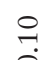 & , & $\hat{0}$ & $\stackrel{+}{\infty}$ & $\stackrel{n}{q}$ & กิ & $\stackrel{n}{m}$ & กै & $\stackrel{N}{N}$ & $\tilde{n}$ \\
\hline & $\tilde{n}$ & $\tilde{n}$ & , & $q$ & & $\begin{array}{l}\infty \\
\text { i }\end{array}$ & $n$ & , & $\stackrel{\infty}{\infty}$ & : & $\hat{~}$ & $\stackrel{ \pm}{\stackrel{5}{0}}$ & $\bar{g}$ & , & , & $\hat{a}$ \\
\hline & దు & $\hat{n}$ & . & $\vec{m}$ & & तิ & $\infty$ & , & , & 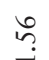 & $\bar{\sigma}$ & ?े & $\stackrel{\infty}{\infty}$ & 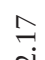 & , & $n$ \\
\hline & $\vec{n}$ & $\stackrel{\leftrightarrow}{\rightarrow}$ & ' & $\begin{array}{l}\infty \\
\infty \\
\dot{0}\end{array}$ & & హె & $\stackrel{0}{\infty}$ & , & $\stackrel{\infty}{\stackrel{\infty}{i}}$ & $\begin{array}{l}\stackrel{b}{\circ} \\
\stackrel{0}{0}\end{array}$ & $\begin{array}{l}\infty \\
: \\
0\end{array}$ & $\begin{array}{l}\vec{n} \\
0\end{array}$ & $\begin{array}{l}b \\
i \\
i\end{array}$ & $\hat{\imath}$ & ' & ชె \\
\hline 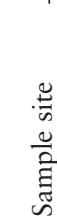 & مإِ & 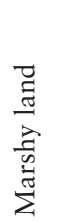 & $\begin{array}{l}\overrightarrow{\widetilde{E}} \\
\text { 麇 }\end{array}$ & 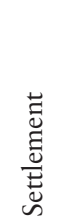 & 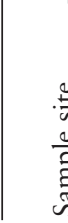 & 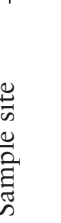 & 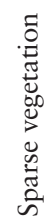 & 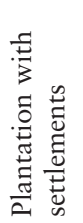 & 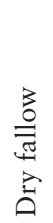 & 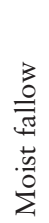 & 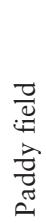 & 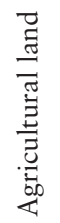 & 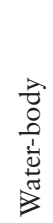 & 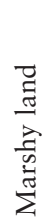 & $\begin{array}{l}\vec{U} \\
\text { ñ }\end{array}$ & 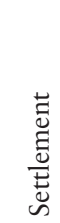 \\
\hline
\end{tabular}




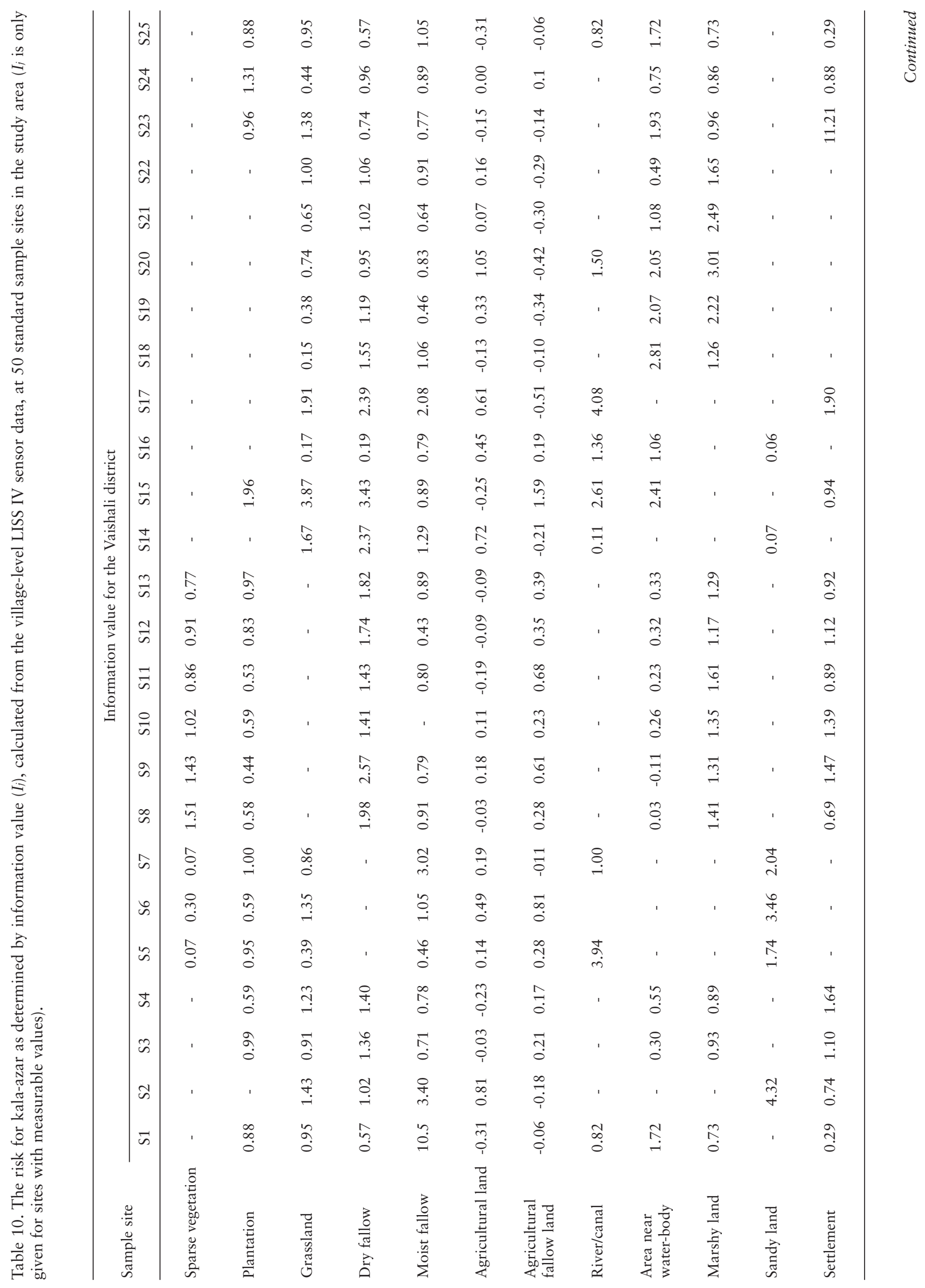




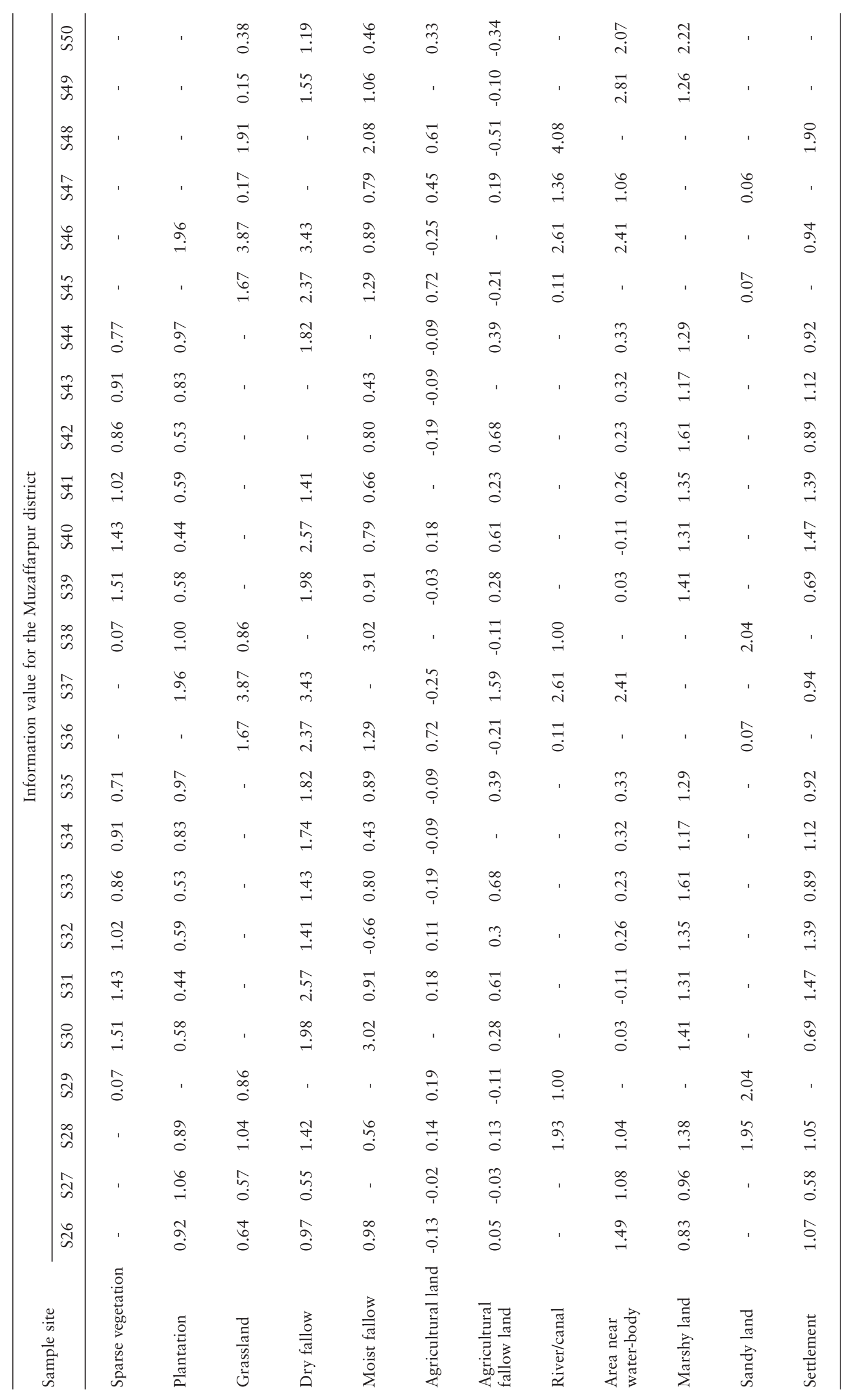


influenced by landscape variables (Kitron, 1998; Sudhakar et al., 2006). In the present study, we focused on the landscape characteristics based on the satellite imagery of various spatial resolutions to delineate significant LULC characteristics influencing disease distribution and vector habitat preferences at different hierarchical levels. The results of the analysis at the national level demonstrate the central role of land cover in shaping sand fly habitats. The potential of low resolution satellite imagery for monitoring and evaluating the factors associated with kala-azar clearly merits further investigation and research. This information has to allow for changing vector bionomics within a biologically meaningful time frame.

The results demonstrate that GLCF 2000 units are capable of accurately translating the different ecological requirements of sand fly populations. Calculation of information values $\left(I_{j}\right)$ of LULC characteristics at the national level showed wide variations in the risk for kala-azar and sand fly habitat suitability across the study area. Though the estimated values of $I_{j}$ were not higher for areas near water-bodies, shrub land and urbanised areas, they still confirm these areas as being at risk and they should be useful for the establishment of a suitability index for sand fly distribution in general.

Some satellites collect environmental data at coarser spatial resolution $(\sim 1000 \mathrm{~m})$ over large geographic regions and are cheaper to acquire compared to images from other land-imaging satellites such as Landsat or IRS P6 that have less frequent revisit capability but higher spatial resolution $(\geq 30 \mathrm{~m})$. Because image availability is an important requirement for the use of satellite data in monitoring the environmental variables associated with fluctuations in, for example, vector populations, any disadvantage of the lower spatial resolution of these satellites may be offset by the benefits of their frequency of observation, low cost and ease of availability. The inclusion of spatially detailed habitat characteristics, as assessed by the detailed, multispectral assessment possible using Landsat ${ }^{\mathrm{TM}}$ data, in addition to coarser resolution multispectral data, provides tactically useful guidance around the distribution of kala-azar vector species. Images obtained from these satellites have a relatively small scene sizes $\left(60-176 \mathrm{~km}^{2}\right)$ and are therefore suitable for relatively small study areas. They have proved to be most useful for local landscape studies of vector habitats, breeding and/or resting sites, where all information is derived from a single satellite image (Kitron et al., 1996; Dister et al., 1997).

Because the P. argentipes vector is typically confined to peri-domestic habitats, multi-spectral images have proved to be less effective than ground survey techniques for identifying residential high risk areas (Hay et al., 2006; Kalluri et al., 2007). However, possibly the LULC classification offered by high-resolution satellite images providing more detailed information (Nagendra and Rocchini, 2008) and the identification of LULC classes based on objects and their spatial relationships, applicable for high-resolution images, can lead to improved classification through better object separability. While the use of local scale approach is still limited, it will hopefully be promoted in the future when sensitivity increases further (Dale and Morris, 1996).

Studies conducted by Sudhakar et al. (2006) suggest that sand fly populations are mainly influenced by three variables, namely, vegetation, water-bodies and settlements which support the adult populations by providing food and shelter. However, the relatively high moisture in areas surrounding non-perennial rivers and other limited water-bodies also play an important role in maintaining sand fly density, promoting transmission of disease at the district and village levels (Bhunia et al., 2011). Indeed, analyses of the impact of remotely sensed land cover features in kala-azar endemic foci have revealed that marshy land, dry and moist fallow tracts, inland surface water-bodies, plantations and settlements are all strongly correlated with kala-azar incidence (Sudhakar et al., 2006; Marzochi et al., 2009; ICMR, 2010). As plantations give way to the construction of weekend cottages or housing for craftsmen finding new work, the sand fly populations in peri-domestic environments increase (Alexander, 1987; Marzochi et al., 2009). The growth in sand fly populations together with new arrival of humans susceptible to Leishmania infection in these areas favour its transmission in certain foci. We show that a detailed assessment of vector habitat, measured here as the area suitable for vector habitat within different spatial scales, increases kala-azar prevalence in the model. The spatial detail present in such models, as well as their demonstrated effectiveness in predicting disease prevalence, permits high-resolution mapping of kala-azar risk of epidemic-prone regions, which should improve the effectiveness of control strategies. These mapping efforts may further provide a baseline to evaluate the impact of kala-azar interventions. The presence of shrub-land and/or grassland also demonstrates some positive influence for predicting the suitable area of kala-azar vectors (El Said et al., 1986; Schlein and Jacobson, 1999) and would be expected to be less 
abundant in areas with little or no vegetation. Within the study area, this could have a negative effect since large quantities of sand and waste are normally carried into the local waterways resulting in the formation of banks covered with herbaceous and bush-like vegetation, botanically regarded as invaders (Dorval et al., 2009).

Our analysis suggests that agricultural land and paddy fields do not establish well-integrated relationships at all hierarchical levels, although to date there is little documented evidence for this. For example, the transmission of leishmaniasis formerly occurred over wide areas from where it has now been eliminated by agricultural development and insecticide treatment. It is known that in relation to rice cultivation, mechanization is likely to be associated with increased flooding and scant vector breeding opportunities (Hunter, 2003; Müller et al., 2011). Moreover, agricultural practices can cause the local extirpation of reservoir hosts, such as the destruction of gerbil habitats (Moškovskij and Duhanina, 1971).

Although, the calculated suitability gave a positive outcome, the mismatches among the four main hierarchical levels (national, state, district and village), as well as intrinsic limitations of low-resolution data sets (AVHRR/MODIS), do not permit this approach to be used for the validation of literature searches. Foremost among the practical problems is the lack of consistent field-based information on the present distribution of sand flies in India. The problem is further compounded by the ability of sand flies to disperse from their resting and breeding sites in search of feeding sources. There are also seasonal variations associated with temperature and humidity fluctuations in the overall sand fly belt distribution limits. These considerations explain why only broad, qualitative suitability classes were applied in this study.

\section{Conclusions}

The growth of the remote sensing technology has provided less costly, low-resolution images capable of predicting sand fly habitats at the national and state levels, while research has not only established the potential of high-resolution images for mapping sand fly habitats at the village level but is now also reaching larger areas. Still, however, the costs involved in purchase and processing of high-resolution datasets limit large-scale application. Our study involved unrestricted, standardised, multipurpose land cover maps to search for habitats suitable for sand flies at much improved scales than used before, which offers extraordinary opportunities to support kala-azar mapping across countries. Land cover maps should also be used to study interactions between kala-azar control and changes in land use, to monitor ecological properties at the landscape scale and, possibly, to define mitigation measures that may remedy any negative environmental impacts.

\section{Acknowledgements}

We are obliged to the Global Land Cover Facility (GLCF) and USDA Earth Explorer community for providing the satellite data free of charge. We are also thankful to the Bihar State Health Society (BSHS), Patna, Bihar, India for providing the disease incidence report. The work was financially supported by the Indian Council of Medical Research (ICMR), New Delhi under the Senior Research Fellowship Grant.

\section{References}

Alexander JB, 1987. Dispersal of phlebotomine sandflies in a Colombian coffee plantation. J Med Entomol 24, 552-558.

Belward AS, Estes JE, Kilne KD, 1999. The IGBP-DIS global 1$\mathrm{km}$ land-cover data set DISCover: a project overview. Photogramm Eng Remote Sens 65, 1013-1020.

Bhunia GS, Kesari S, Chatterjee N, Pal DK, Kumar V, Ranjan A, Das P, 2011. Incidence of visceral leishmaniasis in the Vaishali district of Bihar, India: spatial patterns and role of inland water bodies. Geospat Health 5, 205-215.

Bhunia GS, Kesari S, Jeyaram A, Kumar V, Das P, 2010a. Influence of topography on the endemicity of Kala-azar: a study based on remote sensing and geographical information systems. Geospat Health 4, 155-165.

Bhunia GS, Kumar V, Kumar AJ, Das P, Kesari S, 2010b. The use of remote sensing in the identification of the eco-environmental factors associated with the risk of human visceral leishmaniasis (kala-azar) on the Gangetic plain, in north-eastern India. Ann Trop Med Parasitol 104, 35-53.

Chaves LF, Pascual M, 2006. Climate cycles and forecasts of cutaneous leishmaniasis, a nonstationary vector-borne disease. PLoS Med 3, e295.

Cihlar J, 2000. Land cover mapping of large areas from satellites: status and research priorities. Int J Remote Sens 21, 1093-1114.

Claborn D, Masuoka P, Morrow M, Keep L, 2008. Habitat analysis of North American sand flies near veterans returning from leishmania-endemic war zones. Int J Health Geogr 7, 65. Corsi F, de Leeuw J, Skidmore AK, 2000. Modelling species distribution with GIS. Research techniques in animal ecology; controversies and consequences (Boitani $\mathrm{L}$ and Fuller TK, eds). Columbia University Press, New York, USA, pp. 389-434.

Dale PER, Morris CD, 1996. Culex annulirostris breeding sites 
in urban areas: using remote sensing and digital image analysis to develop a rapid predictor of potential breeding areas. J Am Mosq Control Assoc 12, 316-320.

Dister SW, Fish D, Bros SM, Frank DH, Wood BL, 1997. Landscape characterization of peridomestic risk for lyme disease using satellite imagery. Am Trop Med Hyg 57, 687-692.

Dorval MEC, Cristaldo G, Rocha HCD, Alves TP, Alves MA, Oshiro ET, Oliveira AGD, Brazil RP, Galati EAB, Cunha RVD, 2009. Phlebotomine fauna (Diptera: Psychodidae) of an American cutaneous leishmaniasis endemic area in the state of Mato Grosso do Sul, Brazil. Mem Inst Oswaldo Cruz 104, 695-702.

Elnaiem DE, Schorscher J, Bendall A, Obsomer V, Osman ME, Mekkawi AM, Connor SJ, Ashford RW, Thomson MC, 2003. Risk mapping of visceral leishmaniasis: the role of local variation in rainfall and altitude on the presence and incidence of kala-azar in eastern Sudan. Am J Trop Med Hyg 6, 10-17.

El Said S, Beier JC, El Sawaf BM, Doha S, El Kordy E, 1986. Sand flies (Diptera: Psychodidae) associated with visceral leishmaniasis in El Agamy, Alexandria Governorate, Egypt II. Field behavior. J Med Entomol 23, 609-615.

ELtohamy F, Hamza EH, 2009. Effect of ground control points location and distribution on geometric correction accuracy of remote sensing satellite images. Paper ASAT-13-RS06, 13th International Conference on Aerospace Sciences \& Aviation Technology (ASAT-13), 1-14.

Feliciangeli MD, Delgado O, Suarez B, Bravo A, 2006. Leishmania and sand flies: proximity to woodland as a risk factor for infection in a rural focus of visceral leishmaniasis in west central Venezuela. Trop Med Int Health 11, 1785-1791.

Fernández MS, Salomón OD, Cavia R, Perez AA, Acardi SA, Guccione JD, 2010. Lutzomyia longipalpis spatial distribution and association with environmental variables in an urban focus of visceral leishmaniasis, Misiones, Argentina. Acta Trop 114, 81-87.

Global Land Cover Facility (GLCF), 2000. Available at http://glcf.umiacs.umd.edu/data/gls/ (accessed on June 2011).

Gonçalves JA, Morgado AM, 2008. Use of the SRTM DEM as a geo-referencing tool by elevation matching. The International Archives of the Photogrammetry, Remote Sensing and Spatial Information Sciences Vol. XXXVII, Part B2, Beijing, China, pp. 879-883.

Hay SI, Tatem AJ, Graham AJ, Goetz SJ, Rogers DJ, 2006. Global environmental data for mapping infectious disease distribution. Adv Parasitol 62, 37-77.

Hunter PR, 2003. Climate change and waterborne and vectorborne disease. J Appl Microbiol 94, 37-46.

Indian Council of Medical Research (ICMR), 2010. A compilation of research contribution of the task force project under ICMR- application of GIS and RS technologies in epidemiology and control of vector-borne diseases. Epidemiology and communicable diseases division. V. Ramalingaswami Bhawan,
Ansari Nagar, New Delhi-110029, India, pp. 56-70.

Jung Y, Swain PH, 1993. Robust supervised classification algorithm for multivariate contaminated data based on modified M-estimates. Geoscience and Remote Sensing Symposium, 1993. IGARSS, Tokyo, Japan, pp. 1527-1529.

Kalluri S, Gilruth P, Rogers D, Szczur M, 2007. Surveillance of arthropod vector-borne infectious diseases using remote sensing techniques: a review. PLoS Pathog 3, e116.

Kerr JT, Ostrovsky M, 2003. From space to species: ecological applications for remote sensing. Trends Ecol Evol 18, 299-305. Kitron U, 1998. Landscape ecology and epidemiology of vector borne diseases: tools for spatial analysis. J Med Entomol 35, 435-477.

Kitron U, Otieno LH, Hungerford LL, Odulaza A, Brigham WU, Okello OO, Joselyn M, Mohamed-Ahmed MM, Cook E, 1996. Spatial analysis of the distribution of teste flies in the Lambwe Valley Kenya using Landsat TM satellite imagery and GIS. J Anim Ecol 65, 371-380.

Kolaczinski JH, Reithinger R, Worku DT, Ocheng A, Kasimiro J, Kabatereine N, Brooker N, 2008. Risk factors of visceral leishmaniasis in East Africa: a case-control study in Pokot territory of Kenya and Uganda. Int J Epidemiol 37, 344-352.

Lassau SA, Cassis G, Flemons PKJ, Wilkie L, Hochuli DF, 2005. Using high-resolution multi-spectral imagery to estimate habitat complexity in open-canopy forests: can we predict ant community patterns? Ecography 28, 495-504.

Marzochi MC, Fagundes A, Andrade MV, Souza MB, Madeira MF, Mouta-Confort E, Schubach AO, Marzochi KBF, 2009. Visceral leishmaniasis in Rio de Janeiro, Brazil: eco-epidemiological aspects and control. Rev Soc Bras Med Trop 42, 570580.

Miao X, Gong P, Pu R, Carruthers RI, Heaton JS, 2007. Applying class-based feature extraction approaches for supervised classification of hyperspectral imagery. Can J Remote Sens 33, 162-175.

Moškovskij ŠD, Duhanina NN, 1971. Epidemiology of the leishmaniases: general considerations. Bull World Health Organ 44, 529-534.

Müller GC, Kravchenko VD, Rybalov L, Schlein Y, 2011. Characteristics of resting and breeding habitats of adult sand flies in the Judean Desert. J Vector Ecol 36, 195-205.

Nagendra H, Rocchini D, 2008. High resolution satellite imagery for tropical biodiversity studies: the devil is in the detail. Biodivers Conserv 17, 3431-3442.

Picado A, Singh SP, Rijal S, Sundar S, Ostyn B, Chappuis F, Uranw S, Gidwani K, Khanal B, Rai M, Paudel IS, Das ML, Kumar R, Srivastava P, Dujardin JC, Vanlerberghe V, Andersen EW, Davies CR, Boelaert M, 2010. Longlasting insecticidal nets for prevention of Leishmania donovani infection in India and Nepal: paired cluster randomised trial. BMJ 341, c6760.

Prakash C, 1998. Landslide hazard zonation in Doon Valley using remote sensing and GIS. MSc Thesis, Indian Institute of 
Technology, Kanpur, India.

Rémi A, Huang S, Jiren L, Hervé Y, Yves-Louis D, 2007. Large scale land cover map generation based on low and medium resolution Envisat asar data, application to Poyang Lake area (Jiangxi, P. R. China). Proceedings of the Envisat Symposium 2007, Montreux, Switzerland 23-27 April 2007 (ESA SP-636, July 2007).

Rogers DJ, Williams BG, 1993. Monitoring trypanosomiasis in space and time. Parasitology 106, S77-S92.

Schlein Y, Jacobson RL, 1999. Sugar meals and longevity of the sandfly Phlebotomus papatasi in an arid focus of Leishmania major in the Jordan Valley. Med Vet Entomol 13, 65-71.

Schetselaar E, Tiainen M, Moldai T, 2008. Integrated geological interpretation of remotely sensed data to support geological mapping in Mozambique. Geol S Finl 48, 33-63.

Sudhakar S, Srinivas T, Palit A, Kar SK, Battacharya SK, 2006. Mapping of risk prone areas of kala-azar (visceral leishmania- sis) in parts of Bihar state, India: an RS and GIS approach. J Vect Borne Dis 43, 115-122.

Suresh KG, 1999. Rainfall effect in landslide hazard zonation using remote sensing and GIS. MSc Thesis, Indian Institute of Technology, Kanpur, India.

Turner MD, Congalton RG, 1998. Classification of multitemporal SPOT XS satellite data for mapping rice field on a West Africa. Int J Remote Sens 19, 21-41.

Walton BC, Wijeyaratne PM, Modabber F, 1987. Research on control strategies for the leishmaniases. Proceedings of an International Workshop held in Ottawa, Canada, 1-4 June.

Wilson ML, 2002. Emerging and vector-borne diseases: role of high spatial resolution and hyperspectral images in analyses and forecasts. J Geograph Syst 4, 31-42.

Wulder MA, Hall RJ, Coops NC, Franklin SE, 2004. High spatial resolution remotely sensed data for ecosystem characterization. Bioscience 54, 511-521. 